\title{
Study of growth performance of Desi growing chickens reared under confinement on varying levels of energy and protein
}

\author{
M.Y. Miah ${ }^{1,3 *}$, S D Chowdhury ${ }^{1}$ and A.K.F.H Bhuiyan ${ }^{2}$ \\ ${ }^{1}$ Department of Poultry Science, Bangladesh Agricultural University, Mymensingh, Bangladesh. \\ ${ }^{2}$ Department of Animal Breeding and Genetics, Bangladesh Agricultural University, Mymensingh, \\ Bangladesh. ${ }^{3}$ Department of Poultry Science, Sylhet Agricultural University, Sylhet-3100, Bangladesh.
}

\begin{abstract}
The effects of dietary energy and protein concentration on desi growing chickens under confined management system were evaluated through conductive feeding trial with 72 female desi growing chickens of 12-22 weeks of age. Four experimental diets were i) Conventional diet (CD), ii) low nutrient density (ME $2500 \mathrm{kcal} / \mathrm{kg}+\mathrm{CP} 15 \%$ ), iii) moderate nutrient density (ME $2700 \mathrm{kcal} / \mathrm{kg}+\mathrm{CP} 17 \%$ ) and iv) high nutrient density (ME $2900 \mathrm{kcal} / \mathrm{kg}+\mathrm{CP} 19 \%$ ). The contents of other nutrients including calcium and total phosphorous in the formulated diets were fitted with the requirements of the chickens. Results indicated that feed intake and weight gain increased significantly in birds received increased levels of nutrients in diets. It is concluded that the ME and CP requirements for indigenous (desi) female chicks between 12 and 22 weeks of age may be $2700 \mathrm{kcal} / \mathrm{kg}$ and $17 \%$ diet respectively for achieving proper weight gain before reaching sexual maturity.
\end{abstract}

(Key words: Energy and protein concentration, desi growing chicks, growth performances)

\section{Introduction}

The national share of commercial strain of chickens and indigenous family poultry in terms of egg production is almost equal (50:50) and that of meat production is 60:40 (Bhuiyan, 2011). The rural poultry generally survive on scavenging feed resource with a little or no feed supplementation. The country has got ample opportunity for increasing rural poultry production at small holders' level. Its success primarily depends on the improvement of existing feeding system along with their genetic improvement. Despite low productivity desi chickens are well adapted to rural condition even in adverse agro-climatic conditions (Das et al., 2008). Genetic potentiality of their productivity has not yet been fully explored. Mukherjee, (1987) and Sazzad et al., (1986) stated that inadequate nutrition had much greater effects on scavengers' productivity than the genetic factors. Haque and Rigor (1990) reported that the indigenous laying chicken received only $14 \%$ and $23 \%$ of their requirement of protein and ME. Information in relation to protein and energy requirements of indigenous chicken is however limited. Scavenging feed is far from balanced diet and moreover, it remains

*Corresponding author; myoumsau2003@gmail.com

Bang. J. Livs. Res. Vol. 20 (1 \& 2), 2013: P. 42-47, ISSN 1022-3851 
deficient in terms of protein and energy requirements of bird. Sometimes calcium in layer ration remained imbalanced and fiber exceeds its maximum level (Ukil, 1992; Biswas et al., 2005). Most of the efforts of poultry development activities in Bangladesh have taken place to improve the native stock through cross breeding. Productivity of desi chicken could be improved significantly if the nutrient contents of diets are improved and if such diets are fed under confinement (Chowdhury et al, 2006).

The present study was, therefore, undertaken to determine responses of indigenous (desi) growing chicken to diets of varying levels of crude protein and metabolizable energy formulated with a few unconventional feed ingredients and to determine appropriate nutrient levels required for optimization of production and profitability.

\section{Material and Methods}

Seventy two female chickens of 12 weeks old were divided into 4 dietary groups and they were reared on littered floor in an open house. Each dietary group has three replications having six birds per replication. The experimental house was partitioned into

Table 1. Ingredients and nutrient composition of the experimental diets

\begin{tabular}{lllll}
\hline \multirow{2}{*}{ Ingredients (kg) } & \multicolumn{4}{c}{ Diets } \\
\cline { 2 - 5 } & CD & LND & MND & HND \\
\hline Maize & 0 & 0 & 9 & 28 \\
Rice polish & 31 & 28 & 25 & 16 \\
Wheat Bran & 0 & 22 & 14 & 8 \\
Broken rice & 65 & 36 & 32 & 2.0 \\
Soybean meal & 0 & 6 & 13 & 18 \\
Protein concentrate & 1 & 0 & 0 & 0 \\
Mustard oil cake & 0 & 5 & 3.5 & 7 \\
DCP & 2.22 & 1 & 1 & 1 \\
Methonine & 0 & 0.05 & 0.05 & 0.05 \\
lysine & 0 & 0.05 & 0.05 & 0.05 \\
Salt & 0.5 & 0.5 & 0.5 & 0.5 \\
Lime stone & 0 & 1.6 & 1.6 & 1.6 \\
Vitamin mineral premix & 0.25 & 0.25 & 0.25 & 0.25 \\
Coccidiostat & 0.025 & 0.025 & 0.025 & 0.025 \\
Total & 100 & 100 & 100 & 100 \\
Nutrient composition & & & & \\
M E (kcal/ kg) & 3156 & 2564 & 2737 & 2904 \\
CP (\%) & 11.42 & 15.29 & 17.2 & 19.59 \\
Ca (\%) & 0.752 & 1.135 & 1.12 & 1.117 \\
Total P (\%) & 0.918 & 0.734 & 0.752 & 0.741 \\
Lysine (\%) & 0.437 & 0.779 & 0.903 & 1.033 \\
Methonine (\%) & 0.224 & 0.578 & 0.516 & 0.494 \\
ME: CP & 276.36 & 167.6 & 159.1 & 148.2 \\
\hline
\end{tabular}

Conventional diet (CD): broken rice-65\%+ rice polish-31\%+ PC-1\%, LND =low nutrient density: ME 2500 $\mathrm{kcal} / \mathrm{kg}+\mathrm{CP} 15 \% ; \mathrm{MND}=$ moderate nutrient density: $\mathrm{ME} 2700 \mathrm{kcal} / \mathrm{kg}+\mathrm{CP} 17 \%$ and $\mathrm{HND}=\mathrm{ME} 2900 \mathrm{kcal} / \mathrm{kg}+$ CP $19 \%$. 
12 equal pens ( 3.65 sq. m./pens) by using wire-net and bamboo materials. The ceiling, walls and floor were washed and subsequently disinfected thoroughly. Four grower diets differing in protein and energy contents were formulated for conducting the feeding trial. Dietary treatments consisted of Conventional diet (CD), low nutrient density (LND) (2500 kcal/kg ME \& CP-15\%), moderate nutrient density (MND) $(2700$ $\mathrm{kcal} / \mathrm{kg} \mathrm{ME}+17 \% \mathrm{CP}$ ) and high nutrient density (HND) (2900 kcal $/ \mathrm{kg} \mathrm{ME}+19 \% \mathrm{CP})$.

Data on growth performance and profitability were recorded up to the point of lay. Data of various parameters were subjected to statistical analyses using analysis of variance (ANOVA) in a completely randomized design (CRD). Comparison of mean values and significant differences were determined by least significant difference (LSD) (SAS, 2008).

\section{Results and Discussion}

\section{Growth performance of grower chicks (12-20 weeks)}

The effects of feeding different diets on the performance of the female indigenous (desi) chicks are shown in Table 2 . It is evident that increasing dietary level of $\mathrm{ME}$ and $\mathrm{CP}$ improved growth of experimental chicks. Body weight was significantly improved in MND and HND diets $(P<0.05)$ than the birds of CD and LND diet during the growing period of 12-20 weeks. The trend of higher body weight in MND receiving chicks was clear whereas CD showed lowest trend in body weight during the same period. Body

Table 2. Body weight of desi chicks fed on different nutrient density diets ( 12 to 22 weeks)

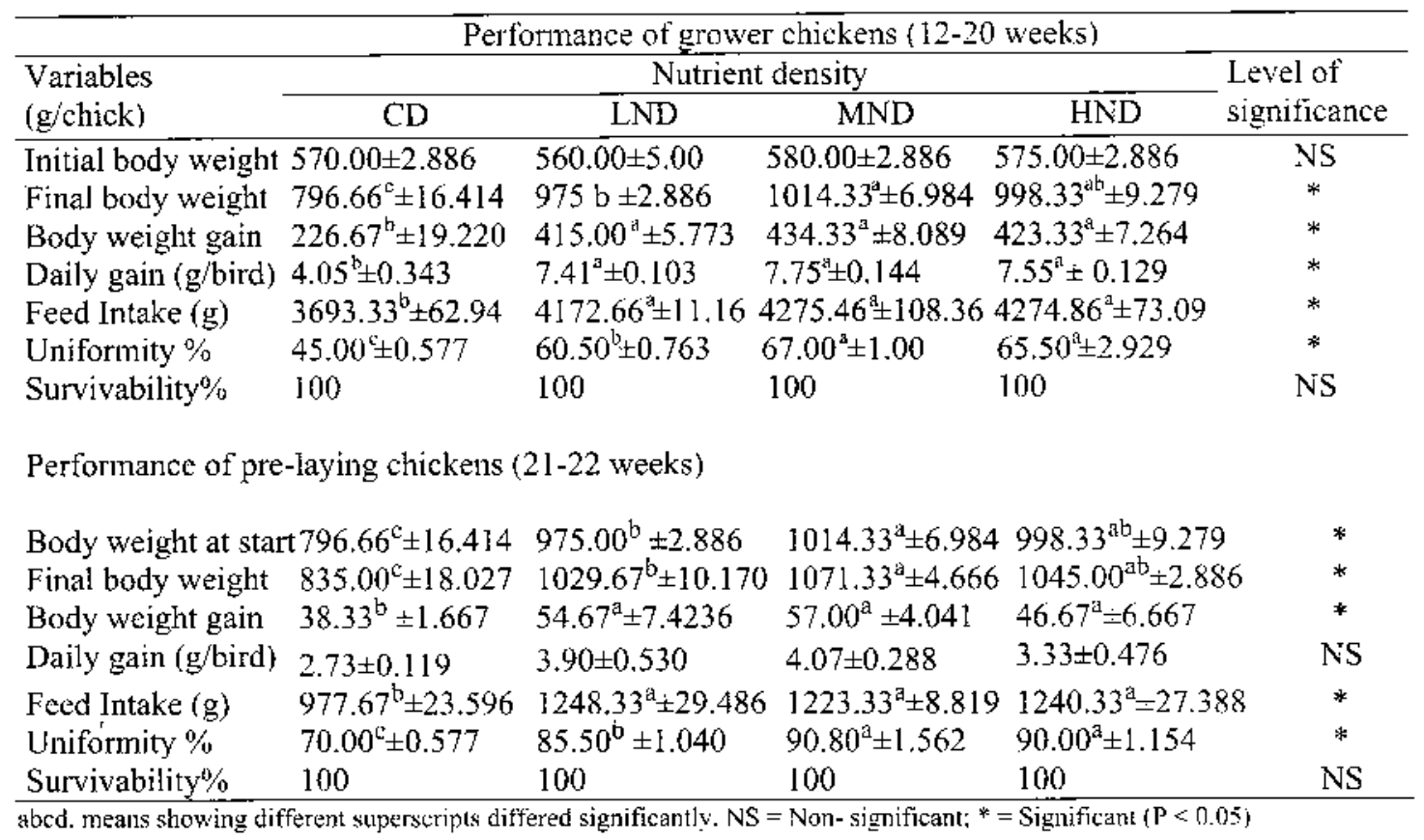


weight gain was significantly improved in MND, HND and LND diets than the birds that received the $\mathrm{CD}$ diet $(\mathrm{P}<0.05)$. Feed consumption was significantly increased in MND, HND and LND diets than the CD diet. The birds on MND diet consumed highest amounts of feed. Uniformity was significantly improved in MND, HND diets than the birds that received the CD and LND diet $(\mathrm{P}<0.05)$. There was no mortality of birds from any treatment groups. Therefore the survivability was $100 \%$ in all groups.

\section{Growth performance of pre-layer chicks (21-22 weeks)}

During the pre-laying period, body weight was significantly $(\mathbf{P}<0.05)$ improved in MND and HND diets in comparison with CD and LND diet. The birds showed no differences in body weight gain (Table 2). The birds on LND diet consumed highest amount of feed that differed significantly from $\mathrm{CD}$ groups. Uniformity was significantly improved in HND, MND diets than the birds that received the $C D$ and LND diet $(\mathrm{P}<0.05)$. The survivability was not affected at all dietary groups during this period.

\section{Profitability analyses}

Data related to cost and return were evaluated (Table 3). Feed cost was highest in HND diet and lowest was in the CD group. Total cost of production was found highest in HND (173.2) diet and lowest was in the control (134.2) group. Total cost of production increased significantly higher in HND than MND, LND and CD group $(\mathrm{P}<0.05)$. Gross return/bird was highest in MND diet and lowest was in CD group $(\mathrm{P}<0.001)$. Gross return/bird increased significantly in HND, MND, and LND than CD group. There is no profit in all dietary groups in the experimental period. Increasing dietary nutrient levels increased significantly BCR $(\mathrm{P}<0.05)$.

It is evident that increasing dietary level of $\mathrm{ME}$ and $\mathrm{CP}$ improved growth of experimental chicks (Table 1). Gondwe and Wollny (2005) found that malawi indigenous grower chicks attained $1077 \mathrm{~g}$ body weight at 20 weeks after feeding a diet containing $18 \%$ Crude Protein and $3200 \mathrm{Kcal} \mathrm{ME} / \mathrm{kg} \mathrm{DM}$ which was close to the result of our moderate nutrient density (MND) diet $17 \%$ CP. Pedersen (2002) obtained daily growth rates of $6.8 \mathrm{~g}$ and $7 \mathrm{~g}$ until week 20 for males and females, respectively. Novak et al., (2007) found that Leghorns grower chicks attained

Table 3. Cost benefit analysis of desi chicks fed on different diets

\begin{tabular}{lccccc}
\hline Variables (BDT) & \multicolumn{4}{c}{ Nutrient density } & Level of \\
\cline { 2 - 5 } & CD & LND & MND & HND & significance \\
\hline Total costs & $317.25^{\mathrm{d}} \pm 1.76$ & $342.24^{\mathrm{c}} \pm .48$ & $348.26^{\mathrm{b}} \pm 2.57$ & $356.21^{\mathrm{a}} \pm 1.86$ & $*$ \\
Gross return & $249.25^{\mathrm{b}} \pm 5.20$ & $300.41^{\mathrm{a}} \pm 3.11$ & $305.83^{\mathrm{a}} \pm 1.12$ & $300.5^{\mathrm{a}} \pm 0.72$ & $*$ \\
Net loss/bird & $68.00^{\mathrm{c}} \pm 6.01$ & $41.83^{\mathrm{a}} \pm 3.48$ & $42.43^{\mathrm{a}} \pm 2.07$ & $55.71^{\mathrm{b}} \pm 1.16$ & $*$ \\
BCR & $0.78^{\mathrm{b}} \pm 0.02$ & $0.87^{\mathrm{a}} \pm 0.01$ & $0.87^{\mathrm{a}} \pm 0.01$ & $0.84^{\mathrm{a}} \pm 0.002$ & $*$ \\
\hline Means showing different superscripts differed significantly. NS $=$ Non- significant; ${ }^{*}=$ Significant $(\mathrm{p}<0.05)$,
\end{tabular}


$9.14 \mathrm{~g} / \mathrm{d}$ body weight gain at 18 weeks after feeding a diet containing $18 \%$ Crude Protein and $2900 \mathrm{Kcal} \mathrm{ME} / \mathrm{kg}$ DM during growing period which was more or less close to the result of our high nutrient density (HND) diet containing $19 \% \mathrm{CP}$ during growing period.

Yeong et al., (1992) reported that village chickens of Zimbabwe reared intensively showed a better growth rate $(1254 \mathrm{~g})$ at 16 weeks of age when fed $18 \%$ CP. Ndegwa et al., (2001) suggested that $17 \%$ CP containing diet was sufficient for Kenyan indigenous grower chicks. The birds on MND diet consumed highest amounts of feed. The results are in agreement with Kingori et al., (2003) who found increased feed consumption in Kenyan indigenous grower chicks with $18 \% \mathrm{CP}$ containing diet. During the pre-laying period, the birds showed no differences in body weight gain (Table 1). The survivability was not affected among the dietary groups at all during this period.

Gross return per bird increased at increasing levels of dietary protein in this study. But there was no profit in any dietary groups when considered on weight basis at 22 weeks of age. Due to slow growth rate and more feed intake, BCR was not satisfactory indicating that birds should not be maintained beyond 22 weeks of age for table purpose. Rather they could be well grown and considered for future egg production, similar to high yielding modern strain. Profit may be earned with such chicks if sale price of birds'could be considered on per bird basis which goes outside the scope of this study.
Thus it is inferred that indigenous chicks could not be raised beyond 14 weeks of age for table purpose.

\section{Conclusion}

During the grower and pre-layer periods of indigenous female pullets, a nutrient density of $2700 \mathrm{ME} \mathrm{kcal} / \mathrm{kg}$ and $17 \% \mathrm{CP}$ (MND) would be enough to optimize feed intake and growth rate. However, this result will have to be confirmed under rural condition where supplemental feeding is practiced in addition to scavenging. Further, a cost-benefit analysis should be kept in mind in future research plan considering the improvement of egg production.

\section{Acknowledgement}

The authors gratefully acknowledge the Ministry of Education, Govt. of the People's Republic of Bangladesh for financing this project.

\section{References}

Bhuiyan, A.K.F.H. 2011. Implementation of National Livestock Development Policy (2007) and National Poultry Development Policy (2008): Impact on smallholder livestock rearers. Keynote paper presented at the South Asia Pro Poor Livestock Policy Programme (SAPPLP)-BRAC workshop held at BRAC Centre Inn, Dhaka.18. 10. 2011.

BIS, 1992. Bureaus of Indian Standards, Indian standards Institute, New Delhi, India. 
Chowdhury, S.D., Ahmed, S. and Hamid, M.A. 2006. Improved feeding of desi chicken reared in confinement. The Bangladesh Veterinarian, 23: 29-35.

Das, S.C., Chowdhury, S.D., Khatun, M.A., Nishibori, M., Isobe, N. and Yoshimura, Y. 2008. Poultry production profile and expected future projection in Bangladesh. World's Poultry Science Joumal, 64: 99-117.

Gondwe T.N., and Wollny C.B.A. 2005. Evaluation of the Growth Potential of Local Chickens in Malawi. International Journal of Poultry Science, 4: 64-70.

Haque, Q.M.E. and Rigor, E.M. 1990. The effect of chick separation on productivity of hens and chicks.Asian Australasian Joumal of Animal Science, 3: 121-123.

Kingori, A.M., Tuitoek, J.K., Muiruriand H.K., and Wachira A.M. 2003. Protein requirements of growing indigenous chickens during the 14-21 weeks growing period. South African Journal of Animal Science, 33:78-82.

Mukherjee, T.K. 1987. Problems and Prospects of Genetic Improvement of Poultry for rural areas in Asia.FAO Expert consultants meeting for Rural Poultry Development in Asia, Dhaka, Bangladesh.

Ndegwa, J.M., Mead, R., Norrish, P., Kimani, C.W. And Wachira, A.M. 2001. The performance of indigenous Kenyan chickens fed diets containing different protein levels during rearing. Tropical Animal Health and Production, 33: 441-448.
Novak C.L., Yakout H.M., and Remus, J. 2007. Response to Varying Dietary Energy and Protein with or Without Enzyme Supplementation on Growth and Performance of Leghorns: Growing Period. Journal of Applied Poultry Research16: 481-493.

Pedersen, C.V. 2002. Production of semiscavenging chickens in Zimbabwe, Ph.D Thesis, The Royal Veterinary and Agricultural University, Copenhagen, Denmark.

Sazzad, M.H. 1986. Reproductive performance of Deshi hens under scavenging and intensive system of rearing. Proceedings of 1 st Annual Livestock Research Workshop Bangladesh Livestock Research Institute Savar Dhaka 60-62.

Ukil, M.A. 1992. Availability of Nutrients to scavenging chickens and duck in Bangladesh.MSc thesis Poultry Science, Bangladesh Agricultural University, Mymensingh, Bangladesh.

Yeong, S.W. 1992. Effect of dietary protein level on growth performance of village chicken. In: Proceedings of the National IRPA. Seminar Agriculture Sector (Eds. Ho,Y. Vidyadaran, M.K. Abduila, Janudin, M.R. and Bahaman, A.R.) 2:519-520. 